\title{
Phylogenetic relations in section Arachis based on seed protein profile
}

\author{
A. K. Singh**, S. Sivaramakrishnan, Melak H. Mengesha, and C. D. Ramaiah \\ Genctic Resources Umi, 1( RISAI, Patancheru, P( ) $\wedge$ P 5(12 324. Inda
}

Recerved November 12. 1990): Aecepted F chruary 4. 1991

communcuated by A. R Hallaver

\begin{abstract}
Summary. Seed proten profiles of nine diplond speces (2n-20), ten tetraplod accessions, two synthetc amphidiploids and two autotetraploids $(2 n=40)$ were studied using SDS-polyalcrylamide gel electrophoresis. While the general profiles suggested considerable homology among these taxil in spite of speciation and plordy differences. appreciable genetic differences were present to support the existing genomic divisions and sub-divisions in the section Arachis. A high degree of relationship wats indicated between the two diploid species (A. durancissis contamng the A genome and A. hatizocoi (IC ( 3 8210) containing the $\mathrm{B}$ genome) and tetraploids A. monticola A. hypogate $(2 \mathrm{n}=40)$ contaning AABB genome. Simular relationships were recorded between the AABB synthetic amphidiploid and the profile obtained from the mixture of protein of 4 . duranemsis and $A$. batzocor. suggesting that these two diploid species were the donors of the $A$ and $\mathrm{B}$ genome, respectively, to tetraploid $A$. monticola A. hipogata.
\end{abstract}

Key words: Aruchus - SDS-PAGE electrophoresis Protein-profile Homology Statistical-distance

\section{Introduction}

Seed proten profiles have been a powerful technique for ascertaining genetic homology at the molecular level and for resolving taxonomic and phylogenetic problems (Ladizinsky and Hymowitz 1979). In the section Arachis

\footnotetext{
* Submitted as Journal Article No. 1114 by International Crops Research Institute for the Semi-Arid Tropics (ICRISAT)

** To whom correspondence should be addressed
}

of the genus Arachis, phylogenetic relationships among different species have been traced on the basis morphological, phytogeographical and cylogenetical data (Singh 1988) These studies revealed that most diploid wild species $(2 \mathrm{n}=20)$ have a common A genome. whereas 1. butizoroi has different genome, designated B. The A and $\mathrm{B}$ genomes are homoeologous and together const1tute the cultivated tetraploid 1. hypogue $(2 \mathrm{n}=40)$ (Smartl et al. 1978: Stalker and Dalmacio 1981; Singh and Moss 1982). Genome analysis (Singh and Moss 1984) and the hybridization of cultuvars of A. hypogate with synthetic amphidiploids of the $A$ and $B$ genome species (Singh 1988) revealed that A. hypogaeu is a segmental allotetraploid evolved through the amphidiploidization of an $\mathrm{AB}$ hybrid. A. hatizoso is believed to be the more probable donor of the B genome and 4 . duramensis and or $A$. villosa of the $A$ genome.

Attempts have been made to establish species relationships among both broad groups and among speces of the section Arachis using seed protein and isozyme profiles and immunochemecal characterization. However, the inferences that can be drawn from these studies are fragmentary and have not always corresponded with those from previous investigations (Cherry 1975; K'lozova et al. 1983 a, b; Krishna and Mitra 1988). The present study is an extension of the genome analyses carried out by Singh and Moss (1982, 1984) and Singh (1988) using the same set of Arachis species and cultigens from A. hypogaea representing a spectrum of genomic vartability. Protein profiles of the amphidiploids, autotetraploids and a mixture of proteins from two of the most probable ancestral wild Arachis species with A and $B$ genomes were also studied to verify earlier conclusions. Only protein profiles were used because they are relatively stable and alter slowly during evolution (Margolaash and Fitch 1968: McDaniel 1970). 


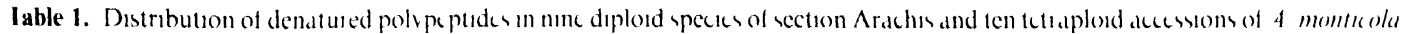
and 4 hipogaca

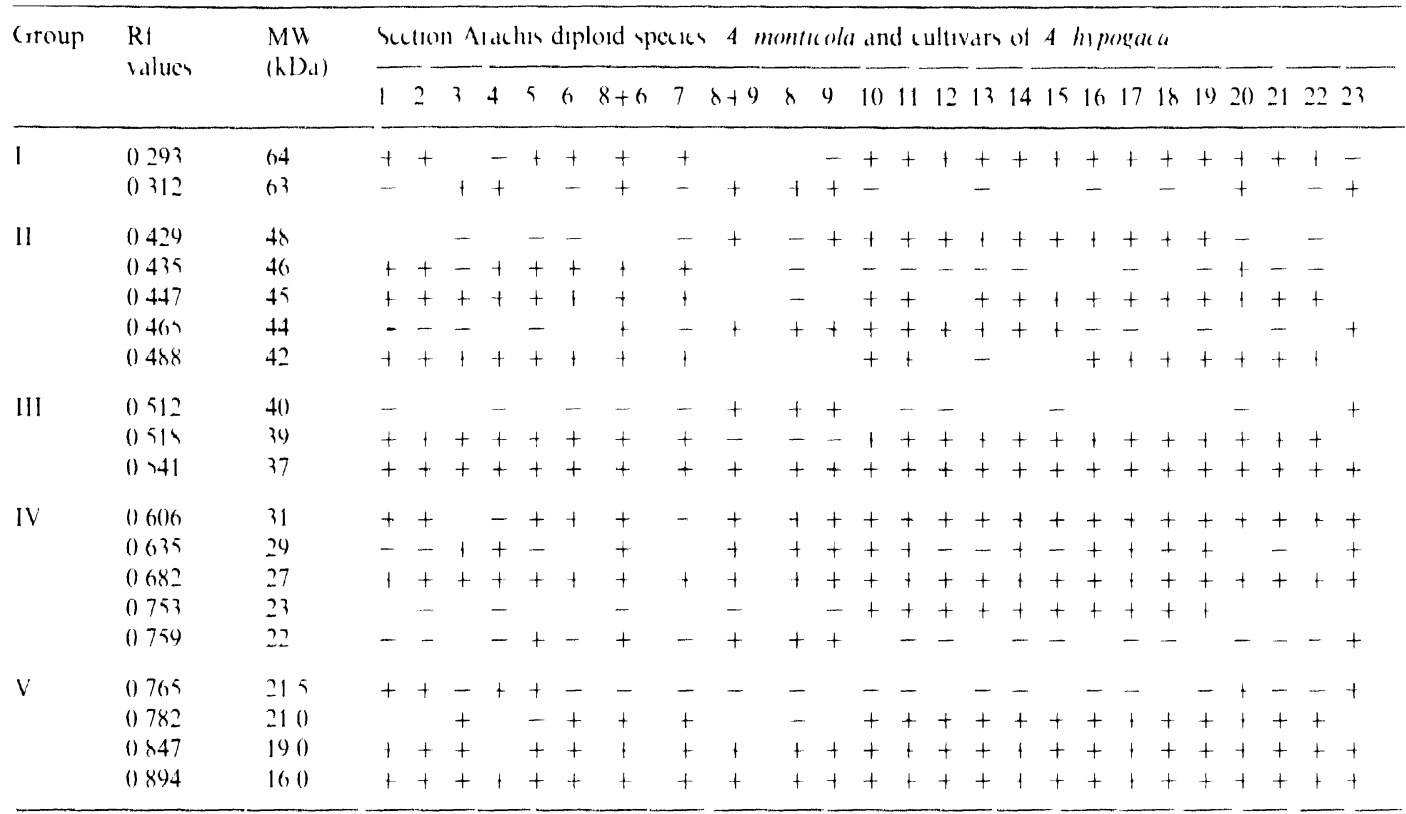

+ Donck present - Doncts absent

MW Moleculdt weight

$1=4$ чp HLK-410 4 hipegaca ssp fastiglata 1 hipogata spp hipogaca 20

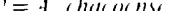

$3=4$ rardenasm 12 IC $(1,736)$

$4=4$ (amlinlma $13 \quad 16(111596$

$5=4$ willosed

$6=4$ dus ame nus

$7=4$ sp 10038

$x-4$ halrocol

$y=4$ sp $30(0) 81$

$10=4$ monticola

$11=4$ sp 30063
4 hipogaca up fartiguta
lat lalkatuls
$14=I C(111175$
4 hipogara ssp hipogaca
$15=I C(11595$
la himpogara
$18 \quad$ IC G 11600
1) IC 612065 rat hipogalea $16=I C(, 10825$

$17=\mathrm{I}((, 120) 64$

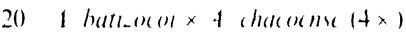
$21=1$ sp 1003 $\times 4$ sp $111 k+10(4 x)$

$22-4$ dun (anc n) $(4 \times)$

$23=4$ hatrom $(4 \times)$

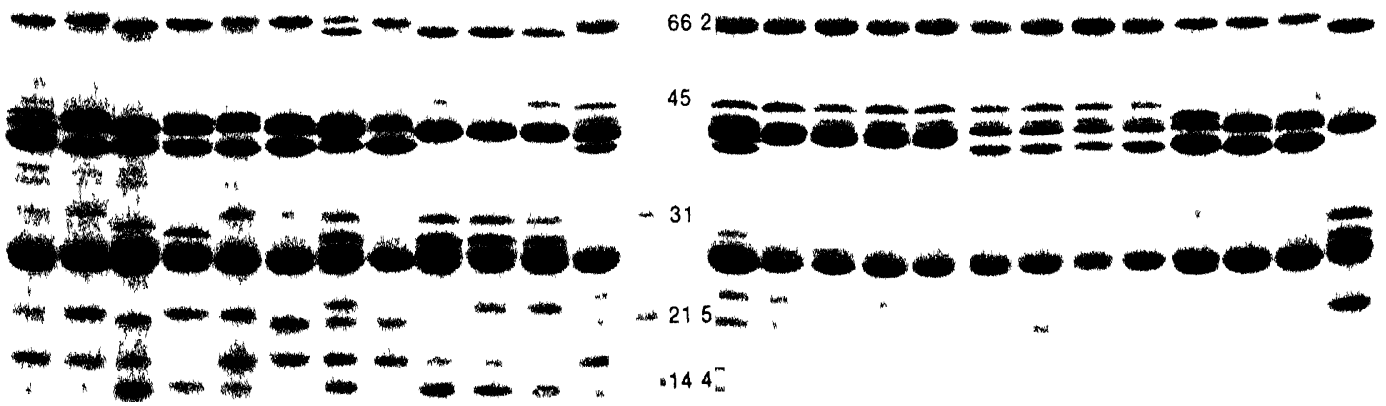

$\begin{array}{llllllllllllllllllllllllll}1 & 2 & 3 & 4 & 5 & 6 & 6+8 & 7 & 8+9 & 8 & 9 & 10 & 10^{a} & 11 & 12 & 13 & 14 & 15 & 16 & 17 & 18 & 19 & 20 & 21 & 22 & 23\end{array}$

Fig. 1. Profiles of seed protein of Alac his species For genotype number see Table 2 Track 10 a contains the moleculal weight markers 


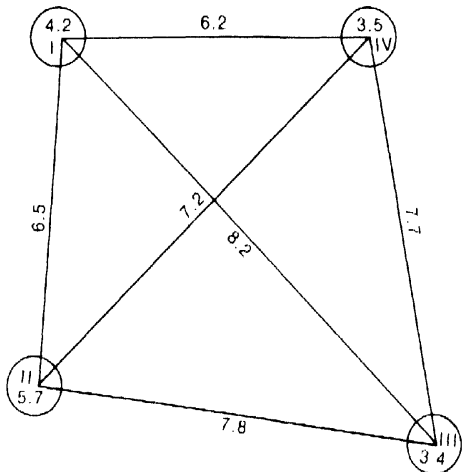

Fig. 2. C'lusters (l-IV) on the basis of perentage dissimilarities laken as the statistical distance between aceessions

\section{Materials and methods}

Details of some taxa used in present investigation have been listed in a previous communication (Singh and Moss 1982). The details of an additional accession of .4. batizoroi. (.4. sp. 30081) and of A. monticola (A. sp. 30063 ) representing other branching hathits, and of the cultigens of A hypegae from four cultivar groups. representing three botanical varieties and two subspecies, are given as foomote in Table 1.

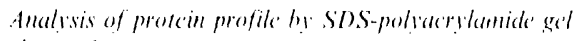
clectrophoresis

One seed of each taxa was decorticated and ground in a mortar with pestle. About $100 \mathrm{mg}$ of powdered sample was defatted with $1 \mathrm{ml}$ "hexanc. The lubes containing the powdered sample were mixed for $30 \mathrm{~min}$ and the hexanc was decanted. The defatled cake was dricd under vacuum. and about $10 \mathrm{mg}$ of the powdered cake was laken for prolein extraction by mixing it with $1 \mathrm{ml}$ buffer (TRIS-H(I $\mathrm{pH} 7.5 .50 \mathrm{mM}$ ) for 60 min. The samples were centrifuged for 5 min at 13,000 rpm in an Eppendorf eentrifuge, the supernatant was removed and the protein was estimated by the Iowry el al. method (1951).

Samples were treated with TRIS hulfer containing sodium dodecyl sulfate (SDS), glycerol and bromophenol blue according to the method of Lacmmli (1970). Llectrophoresis was conducted on $12.5 \%$, polyacrylamide slab gels containing SDS by loading samples containing equal amounts of protein; the gels were later stained with Coomassic Brilliant Blue (i-250. The molecular weight markers used were: phosphorylase b. $92.5 \mathrm{kDa}$; bovine serum albumin, $66.2 \mathrm{kDa}$; ovalbumen, $45 \mathrm{kDa}$; carbonic anhydrase, $31 \mathrm{kDa}$; soybean trypsin inhibitor $21.5 \mathrm{kDa}$, and lysoryme $14.4 \mathrm{kDa}$.

Variations in the position of the bands in any lane were expressed in Resolution factor (RO) values. The bromophenol blue dye front at the bottom of the gel was arbitrarily given the value 1 , while the top of the gel was given a value of zero. The Rf value of a particular variant band was proportional to the distance between the two reference standards (i.c.. 0 and 1). The Rf value for each band was compuled from the mean of observations obtained from threc independent electrophoretic runs of separate extractions.

The percentage similarity between different pairs of species and culligens was calculated by adapting the method of Ladizinsky and Hymowitz (1979).

Treating percentage dissimilarity as the generalized statistical distance, we grouped the taxa into clusters using the Tocher method (Rao 1952).

\section{Results}

The protein profiles of 23 species and cultigens are presented in electrophoregrams (Table 1, Fig. 1). A total of 19 bands were resolved in these taxa. The maximum number of bands in any taxon (i.e., 14) was recorded in the tetraploid $A$. monticola. Rf values of these bands ranged from 0.293 to 0.894 . On the basis of $R f$ values the bands were classified into five groups: (1) very slow moving $(0.293 \quad 0.312)$, (2) slow moving $(0.4290 .488)$, (3) medium moving $(0.5120 .541)$, (4) fast moving $(0.606$ $0.759)$ and (5) very fast moving $(0.765 \cdots 0.894)$ ( Tablc 1 ).

\section{Diploid species $(2 n=2(0)$}

Seven species from genome $A$ and two accessions of A. hatizocoi containing genome $\mathrm{B}$ showed a similar numher of total bands. The A genome species had a greater number of similar bands and thereby a higher percent similarity $(50-100 \%)$. They displayed a greater genetic homology among themselves than they did with the two accessions of A. hatizocoi and. therefore, statistically formed a separate clusters (Figs. 1. 2; Table 2). Within the genome A species, A. stenocarpa and A. chacoense (Fig. 1. lanes 1 and 2) had an identical number of bands with similar mobility and thereby $100 \%$ genetic homology, but certain bands in $A$. chacochse did not resolve to a similar intensity, particularly in group II at $\mathrm{Rf}$ values $0.429,0.435$ and 0.447 . A. cardenasii and $A$. correntina had the least number of similar bands with other $A$ genome species with percentage similarity ranging from $47 \%$ to $67 \%$. On the basis of dissimilarity, these two species statistically formed another group (Fig. 2). The other A genome species, A. stenocarpa. A. chacoense. A. villosa. A. duranensis and Arachis sp. 10038 and the synthetic autotetraploids and amphidiploids were genetically similar with percentage similarity ranging from $54 \%$ to $100 \%$. The two A. batizocoi accessions formed one group with its tetraploid and differed from each other by a single band at $\mathrm{Rf}$ value 0.429 . Arachis sp. 10038 (A genome) had the highest $(53 \%)$ number of similar bands to that of $A$. batizocoi.

\section{Tetraploid specties $(2 n=40)$}

The protein profile of tetraploid $A$. monticola revealed the largest number of bands. The majority of these were also expressed in cultivars of $A$. hipogae' $a$, except for bands at $R f$ values of $0.465,0.488$ and 0.635 , which are present in the cultivars of one subspecies and absent in cultivars of another subspecies. Statistically, the cultivars belonging to subspecies hypogaea with $93 \%$ similarity were closer to $A$. monticola than the cultivars belonging to subspecies fastigiata. Protein profiles of two accessions of $A$. monticola were identical with $100 \%$ genetic homology, although morphologically they differed in 
Table 2. Percentage similarities between diploid species of section Arachis and tetraploid aceessions of A. momticola and A. hypogate

\begin{tabular}{|c|c|c|c|c|c|c|c|c|c|c|c|c|c|c|c|c|c|c|c|c|c|c|c|c|}
\hline Taxa 1 & 2 & 3 & 4 & 5 & 6 & $8+6$ & 7 & $8+9$ & 8 & 9 & 10 & 11 & 12 & 13 & 14 & 15 & 16 & 17 & 18 & 19 & 20 & 21 & 22 & 23 \\
\hline 1 & 100 & 50 & 62 & 92 & 83 & 63 & 75 & 29 & 31 & 29 & 56 & 56 & 47 & 53 & 50 & 53 & 60 & 60 & 60 & 60 & 8.5 & 75 & 75 & 38 \\
\hline 2 & & 50 & 62 & 92 & 8.3 & 6.3 & 75 & 29 & 31 & 29 & 56 & 56 & 47 & 53 & 50 & 53 & 60 & 60 & 60 & 60 & 8.5 & 75 & 75 & 38 \\
\hline 3 & & & 67 & 47 & 62 & 67 & 67 & 40 & 4.3 & 40 & 60 & 60 & 40 & 47 & 53 & 47 & 64 & 64 & 64 & 64 & 64 & 67 & 67 & 40 \\
\hline 4 & & & & 57 & 50 & 56 & 54 & 31 & 33 & 31 & 41 & 41 & 24 & 29 & 35 & 29 & 44 & 44 & 44 & 44 & 64 & 4.3 & 43 & 40 \\
\hline 5 & & & & & 77 & (6) & 69 & 35 & 38 & 35 & 53 & 53 & 44 & 50 & 47 & 50 & 56 & 56 & 56 & 56 & 79 & 69) & (1) & 44 \\
\hline 6 & & & & & & 73 & 91 & 29 & 31 & 29 & 67 & 67 & 57 & 64 & 60 & 64 & 71 & 71 & 71 & 71 & 8.5 & 91 & 91 & 29 \\
\hline $8+6$ & & & & & & & 67 & 53 & 56 & 53 & 71 & 71 & 53 & 59 & 65 & 59 & 65 & 6.5 & 6.5 & 6.5 & 75 & 67 & 67 & 53 \\
\hline 7 & & & & & & & & 24 & 25 & 24 & 60 & 60 & 50 & 57 & 53 & 57 & 64 & 64 & 64 & 64 & 77 & 82 & 82 & 24 \\
\hline $8+9$ & & & & & & & & & 91 & 100 & 47 & 47 & 47 & 44 & 50 & 44 & 41 & 41 & 41 & 41 & 3.3 & 31 & .31 & 8.3 \\
\hline 8 & & & & & & & & & & 91 & 41 & 41 & 40 & 38 & 44 & 38 & 35 & .35 & 35 & 35 & 35 & 33 & 3.3 & 91 \\
\hline 9 & & & & & & & & & & & 47 & 47 & 47 & 44 & 50 & 44 & 41 & 41 & 41 & 41 & 3.3 & 31 & 31 & 83 \\
\hline 10 & & & & & & & & & & & & 100 & 79 & 86 & 93 & 86 & 93 & 93 & 93 & 93 & 59 & 71 & 71 & 30 \\
\hline 11 & & & & & & & & & & & & & 79 & 86 & 93 & 86 & 93 & 93 & 93 & 9.3 & 59 & 71 & 71 & 39 \\
\hline 12 & & & & & & & & & & & & & & 92 & 85 & 92 & 71 & 71 & 71 & 71 & 50 & 62 & 62 & $3 x$ \\
\hline 1.3 & & & & & & & & & & & & & & & 92 & 100 & 79 & 79 & 79 & 79 & 56 & (1) & 69 & 35 \\
\hline 14 & & & & & & & & & & & & & & & & 92 & 86 & 86 & 86 & 86 & 53 & 64 & 64 & 41 \\
\hline 15 & & & & & & & & & & & & & & & & & 79 & 79 & 79 & 79 & 50 & 69 & (1) & 35 \\
\hline 16 & & & & & & & & & & & & & & & & & & 100 & 100 & 100 & 6.3 & 77 & 77 & 33 \\
\hline 17 & & & & & & & & & & & & & & & & & & & 100 & 100 & 0.3 & 77 & 77 & 3.3 \\
\hline 18 & & & & & & & & & & & & & & & & & & & & 100 & 6.3 & 77 & 77 & 33 \\
\hline 19 & & & & & & & & & & & & & & & & & & & & & 6.3 & 77 & 77 & 33 \\
\hline 20 & & & & & & & & & & & & & & & & & & & & & & 77 & 77 & 41 \\
\hline 21 & & & & & & & & & & & & & & & & & & & & & & & 100 & 31 \\
\hline 22 & & & & & & & & & & & & & & & & & & & & & & & & 31 \\
\hline 23 & & & & & & & & & & & & & & & & & & & & & & & & \\
\hline
\end{tabular}

see Table 1

their branching pattern. Protein profiles of cultivars belonging to the two cultivar groups of subspecies fastigiana resolved minor differences, but not those of cultivars belonging to the subspecies hypogaea.

\section{Diploid species versus tetraploid species}

Most of the bands that were resolved in diploid species with the $\mathrm{A}$ or $\mathrm{B}$ genome were also present in tetraploid A. monticola and cultivars of A. hypogaea. However, a band resolved at $\mathrm{Rf}$ value 0.435 in almost all $\mathrm{A}$ genome species and a band of Rf value 0.512 resolved in $\mathrm{B}$ genome of $A$. hatizoco $i$ were absent from the profiles of tetraploid taxa; an additional band at $\mathrm{Rf}$ value 0.753 was present.

\section{Experimental polyploids}

In the profiles of the amphidiploid and autotetraploids, the $A$. hatizoco $x$ A chacoense (AABB) amphidiploid resolved the highest number of 13 bands with $47.59 \%$ bands being similar to those observed in tetraploid $A$. monticola and cultivars of $A$. hypogaea. The profile from the mixture of proteins of $A$. hatizocoi and $A$. duranensis (the two most probable ancestors of $A$. hypogaea) resolved 15 bands with $71 \%$ similarity to that of $A$. monticola.

The clustering on the basis of percentage dissimilarity ftaken as an indication of genetic non-homology and divergence) als per Tocher's method resulted in four groups (Fig. 2). (iroup I contains mostly A genome species along with autotetraploids and amphidiploids; group II. A. cardenasii and A. correntina; group III, two accessions of $A$. hatizocoi and its autotetraploid: group IV, all tetraploid taxa.

\section{Discussion}

The protein profiles in the taxa studied have the potential to trace intra- and interspecific relationships among species of section Arachis. The consistency of the protein profile suggests that each species has a reproducibly stable profile as a consequence of its specific gene arrangement (Ladizinsky 1975).

The largest fraction of the protein profiles in the species of section Arachis were homogenous even after ploidy differences, corroborating the conclusions of Klo7ova et al. (1983 b) based on immuno-chemical methods. This suggests that they belong to a common ancestral stock. Percentage similarity of bands (Table 2) and statistical distance calculated over dissimilarity (Fig. 2) reflect, however, appreciable genetic variability among them and also among the diploid species within a genome. $A$. cardenasii and $A$. correntina differed from the A genome species with a significantly lower number of similar bands (Fig. 2), suggesting a sub-group status. Singh and 
Moss (1982) inferred the same for $A$. cardenasii based on karyomorphology. Differences resolved between $A$. c'orrentina and $A$. villosa (earlier suggested to be varieties of the same species) and other A genome species represent minor genetic differences between these taxa. It justifies the separate specific entity of $A$. correntina (Klozova et al. 1983 b). Arachis sp. 30081 has a profile nearly identical to that of $A$. batizocoi except for an additional band at Rf value 0.429 , indicating a higher homology between the two taxa. The presence of the 48-kDa polypeptide in all of the tetraploid taxa places Arachis sp. 30081 closer to them with a greater probability of being a donor of the B genome to $A$. monticola and $A$. hypogaea than the earlicr accession of $A$. hatizoroi (9484).

Among the tetraploid taxa, the accessions of $A$. menticola and the cultivars of $A$. hypogate expressed higher levels of similarity $(71-100 \%)$ in their bands. Statistically, they werc included in one group (Fig. 2), suggesting that these are forms of the same basic species with minor genetic differenees (Singh and Moss 1984). The nearly identical profiles among the cultivars of A. hypogarea subspecies hypogaca indicate that electrophoresis of denatured protein at $12.5 \%$ gel does not resolve the minor genetic differences that may have occurred at the microevolutionary level.

Most of the genetic factors resolved by electrophoresis of the $A$ and $B$ genome diploid species can be traced 10 the A. monticola and A. hypogaea accessions. For example, major polypeptides observed in different mobility groups of $\Lambda$ genome species and in $B$ genome accession Arachis sp. 30081 were also found in the $A$. monticola. and $A$. hypogaca accessions (Fig. 1, Table 1). This confirms earlier postulations that a hybrid of the $A$ and B genome species has evolved A. monticola. Since A. monticola is a tetraploid, it must have evolved through the process of amphidiploidization. This was also visible by the tetrameric nature of certain darker bands.

A. duranensis with the A genome had a higher number of similar bands $(67 \%)$ to A. monticola than any other diploid species, and thus it was the probable donor of the A genome to A. monticola. This supports our earlier conclusions based on cytogenetic evidence (Singh and Moss 1982, 1984: Singh 1988) and does not support the suggestions by Cherry (1975) for $A$. villosa and by Krishna and Mitra (1988) for A. cardenasii. Similarly, Arachis sp. 30081 seems to be the B genome donor. These inferences were corroborated by the mixed protein profile of $A$, duran'nsis and $A$. hatizocoi with $71 \%$ genetic homology to $A$. monticola, and the profile of $\triangle \triangle \mathrm{BB}$ synthetic amphidiploid ( $A$. hatizocoi $\times$ A. chacoense) with
$59 \%$ homology. However, this synthetic amphidiploid statistically groups with the A genome species probably because of the dominance of the genetic factors contributed by the A genome. The protein profiles of section Arachis species were less differentiated and suggest $A$. duranensis and $A$. batizocoi (accession 30081) as the most probable ancestor of $A$. hypogaca.

\section{References}

Cherry JP (1975) Comparative studies of seed proteins and enrymes of species and collections of Arachis by gel electrophoresis. Peanut Sci 2:57-65

Klozova E, Svachulova J, Smartl J, Hadac E. Turkova V, Hadacova $V$ (1983a) The comparison of seed protein pattern within the genus Arachis by polyacrylamide gel electrophoresis. Biol Plant 25:266-27.3

Klomova L. Turkova V. Smartt J, Pitterova K, Svachulova J (1983 b) Immunochemical characterization of seed protein of some species of the genus Arachis L. Biol Plant 25:201 208

Krishna TG, Mitra R (1988) The probable genome donors to Arachis hypergaea $\mathrm{L}$. based on arachin seed storage protein. Euphytica $37: 47 \quad 52$

Ladizinsky $G$ (1975) Seed protein electrophoresis of the wild and cultivated species of section Faba of I'icia. Fuphytica $24: 78.5788$

Ladizinsky (i. Hymowity T (1979) Seed protein electrophoresis in taxonomic and evolutionary studies. Theor Appl Genet $54: 145 \cdots 151$

Laemmli UK (1970) Cleavage of structural protein during the assembly of the head of bacteriophage 14. Nature 227:680685

Lowry OH, Rosebrough NJ, Farr AL, Randall RJ (1951). Protein measurement with the Folin-phenol reagent. J Biol ('hem 193:265-275

Margolaish F. Fitch WM (1968) Fvolutionary variability of cytochrome (' primary struclure. Ann NY Acad Sci $151: 359-381$

McDanicl R( 3 (1970) Flectrophoretic characterization of protein in Hordeum. J Hered 61:243-247

Rao ( R (1952) Advanced statistical methods in biometric research. John Wiley and Sons, New York

Singh AK (1988) Putative genome donors of Arachis hypogaea (Fabacea), evidence from crosses with synthetic amphidiploids. Plant Syst Fvol 160:143-151

Singh AK, Moss IP (1982) Utilization of wild relatives in genetic improvement of Arachis hypogaca L. 2. Chromosome complements of species of section Arachis. Theor $\Lambda$ ppl Genel $61: 305-314$

Singh AK, Moss JP (1984) Utilization of wild relatives in genetic improvement of Arachis hypogaea L. 5 (ienome analysis in section Arachis and its implications in gene transfer. Theor Appl Genet 68:355-364

Smartt J, Gregory WC. Gregory MP (1978) The genome of Arachis hypogaea I. Cytogenetic studies of putative genome donors. Euphytica 27:665-675

Stalker HT, Dalmacio RD (1981) Chromosomes of Arachis species, Section Arachis. J Hered 72:403.408 